DedikasiMU (Journal of Community Service)

Volume 3, Nomor 1,Maret 2021

\title{
SISTEM INFORMASI DESA BERBASIS WEB DI KELURAHAN SIDOMUKTI KECAMATAN KEBOMAS KABUPATEN GRESIK
}

\author{
${ }^{1}$ Pressa Perdana S.S., M. ${ }^{2}$ Fahrudin, ${ }^{3}$ M. Khoirun Nasikin, ${ }^{4}$ Umi Chotijah, \\ ${ }^{5}$ Andi Rahmad Rahim, ${ }^{6}$ Sukaris, ${ }^{7}$ Nur Fauziyah \\ ${ }^{1}$ Dosen Program Studi Elektro, Universitas Muhammadiyah Gresik \\ ${ }^{2}$ Mahasiswa Program Studi Teknik Informatika, Universitas Muhammadiyah Gresik \\ ${ }^{3}$ Mahasiswa Program Studi Teknik Informatika, Universitas Muhammadiyah Gresik \\ ${ }^{4}$ Dosen Program Studi Teknik Informatika, Universitas Muhammadiyah Gresik \\ ${ }^{5}$ Dosen Program Studi Budidaya Perikanan, Universitas Muhammadiyah Gresik \\ ${ }^{6}$ Dosen Program Studi Manajemen, Universitas Muhammadiyah Gresik \\ ${ }^{7}$ Dosen Program Studi Pendidikan Matematika, Universitas Muhammadiyah Gresik \\ Email : fahrudin280@gmail.com
}

\begin{abstract}
ABSTRAK
Di era digitalisasi yang semakin pesat menuntut perkembangan teknologi informasi sebagai kebutuhan yang sangat penting untuk menggali berbagai informasi yang dibutuhkan dan untuk meningkatkan efisiensi dalam hal pelayanan masyarakat. Kelurahan Sidomukti merupakan Kelurahan padat penduduk yang mayoritas berprofesi Pekerja pabrik \& Wirausaha dibidang makanan ringan (jajan pasar), Pengrajin Perhiasan Imitasi, kerudung \& Tas yang membutuhkan percepatan pelayanan dari perangkat kelurahan. Serta terdapat situs giri kedaton yang merupakan sebuah "kerajaan" agama Islam di daerah Gresik sekitar abad ke-15 sampai 17. Potensi-potensi tersebut belum sepenuhnya terekspose didunia maya. Program ini bertujuan untuk membangun sebuah sistem informasi berbasis web untuk meningkatkan pelayana masyarakat dan mengekspose sejarah, profil kelurahan serta mengoptimalkan keberadaan kekayaan budaya yang ada di Kelurahan Sidomukti agar informasi tentang kekayaan tersebut bisa tersampaikan keseluruh pengguna internet sehingga bisa meningkatkan minat wisatawan dan memajukan UMKM dan meningkatkan pendapatan masyarakat dan desa..
\end{abstract}

Kata Kunci: Kelurahan Sidomukti, Giri Kedaton, Sistem Informasi Desa. 


\section{DedikasiMU (Journal of Community Service)}

Volume 3, Nomor 1 ,Maret 2021

\section{PENDAHULUAN}

Kabupaten Gresik adalah sebuah Kabupaten di Provinsi Jawa Timur, Indonesia. Kabupaten Gresik memiliki luas sekitar 1.191,25 km², terbagi dalam 18 kecamatan dan terdiri dari 330 desa dan 26 kelurahan. Kelurahan Sidomukti merupakan salah satunya. Kelurahan Sidomukti memiliki potensi Wisata Religi yang kental dengan Sejarah Giri kedaton, adalah sebuah "kerajaan" agama Islam di daerah Gresik, Jawa Timur sekitar abad ke-15 sampai 17. Kerajaan ini pernah berjaya sebagai pusat agama Islam yang pengaruhnya bahkan sampai menyebar ke daerah Maluku.

Penerapan sistem informasi yang berbasis website merupakan salah satu upaya memajukan potensi Kelurahan Sidomukti sehingga khalayak luas dapat mengetahui berbagai potensi, informasi-informasi penting, dan keindahan alam terkait Kelurahan Sidomukti melalui media internet.

Tujuan dari pembuatan "Sistem Informasi Berbasis Web Kelurahan Sidomukti” adalah program untuk meningkakan efektifitas pelayanan masyarakat dan mengangkat Kelurahan Sidomukti di masyarakat luas, terutama potensi dan berbagai wisata yang dimiliki.

Manfaat bagi Kelurahan Sidomukti dengan adanya sistem ini adalah memudahkan interaksi antara penduduk dengan perangkat kelurahan dalam hal pelayanan sehingga mempercepat lajunya birokrasi. dan dapat digunakan untuk mengenalkan kepada masyarakat luas tentang srtuktur organisasi, kegiatan- kegiatan, potensi, dan wisata yang ada di Kelurahan Sidomukti agar lebih efektif dan efisien. Produk yang diproduksi oleh masyarakat Kelurahan Sidomukti dapat dikenalkan pada masyarakat luas agar semakin banyak konsumen yang membeli produk yang dihasilkan dari Kelurahan Sidomukti, serta memancing minat masyarakat luas untuk berkunjung ke kelurahan Sidomukti untuk Berwisata di Kelurahan sidomukti.

\section{KAJIAN PERSOALAN}

Masyarakat Kelurahan Sidomukti Merupakan masyarakat yang majemuk, yang mayoritas pekerja pabrik dan banyak juga masyarakat yang berkecimpung dalam bidang Wirausaha. Pelanggan yang membeli produk yang dihasilkan masih banyak yang dari Kelurahan Sidomukti dan sekitarnya. 


\section{DedikasiMU (Journal of Community Service)}

Volume 3, Nomor 1 ,Maret 2021

Dalam Era saat ini sangat memungkinkan untuk mencari dan menyebarkan informasi melalui internet tanpa batas. Dengan adanya internet masyarakat dapat mengakses informasiinformasi yang dibutuhkan dan menyediakan informasi untuk keperluan tertentu. Informasi tentang Kelurahan Sidomukti dan juga produk-produk yang dihasilkan dari Keluahan Sidomukti dapat ditampilkan dalam web tersebut.

Internet adalah seluruh jaringan komunikasi yang menggunakan media elektronik, yang saling terhubung menggunakan standar sistem global Transmission Control Protocol/Internet Protocol Suite (TCP/IP) sebagai protokol pertukaran paket (packet switching communication protocol) untuk melayani miliaran pengguna di seluruh dunia. Rangkaian internet yang terbesar dinamakan Internet. Cara menghubungkan rangkaian dengan kaidah ini dinamakan internetworking ("antarjaringan").

Web server adalah sebuah software yang memberikan layanan berbasis data dan berfungsi menerima permintaan dari HTTP atau HTTPS pada klien yang dikenal dan biasanya kita kenal dengan nama web browser (Mozilla Firefox, Google Chrome) dan untuk mengirimkan kembali yang hasilnya dalam bentuk beberapa halaman web dan pada umumnya akan berbentuk dokumen HTML.

Website atau Situs dapat diartikan sebagai kumpulan halaman-halaman yang digunakan untuk menampilkan informasi, gambar gerak, suara, dan atau gabungan dari semuanya itu baik yang bersifat statis maupun dinamis yang membentuk satu rangkaian bangunan yang saling terkait dimana masing-masing dihubungkan dengan link-link.

Domain Name adalah nama unik yang diberikan untuk mengidentifikasi nama server komputer seperti web server atau email server di jaringan komputer ataupun internet.

Nama Domain berfungsi mempermudah pengguna di internet untuk melakukan akses ke server dan mengingat server yang dikunjungi dibandingan harus mengenal deretan nomor atau yang dikenal IP address. Nama domain juga di kenal sebagai sebuah kesatuan dari sebuah situs web.

Hosting (disebut juga Web Hosting / sewa hosting) adalah penyewaan tempat untuk menampung data-data yang diperlukan oleh sebuah website dan sehingga dapat diakses lewat Internet. Data disini dapat berupa file, gambar, email, aplikasi/program/script dan database. 


\section{DedikasiMU (Journal of Community Service)}

Volume 3, Nomor 1,Maret 2021

\section{METODE PELAKSANAAN}

Pembuatan Website Kelurahan Sidomukti memiliki 5 tahap.

1. Obyektif - Menentukan maksud dan tujuan pembuatan website.

2. Desain - menyangkut desain grafis atau multimedia, tetapi harus sesuai dengan obyektif. Dalam desain, harus ditentukan juga layout, struktur menu, dan yang paling penting materi. Materi termasuk profil yang ingin ditampilkan, bisnis, barang/jasa, dan lain sebagainya. Materi web yang baik dan memberi manfaat bagi pengunjung akan mendatangkan trafik yang bagus.

3. Pembuatan - Secara umum, pembuatan web dapat dikelompokan dalam 2 cara; Membuat sendiri web dan program dari awal. Cara ini memerlukan tim yang memiliki berbagai keahlian seperti HTML, CSS, Javasript, desain grafis (Photoshop), dan pemrograman skrip web (PHP, JSP, ASP).

4. Menggunakan CMS (Content Management System) seperti WordPress atau Joomla . CMS adalah platform siap pakai yang bisa di"custom" agar sesuai dengan kebutuhan kita.

5. Menggunakan Bahasa PHP Native yang diperuntukkan membuat website dan sudah teruji kestandartan dan kestabilannya untuk website.

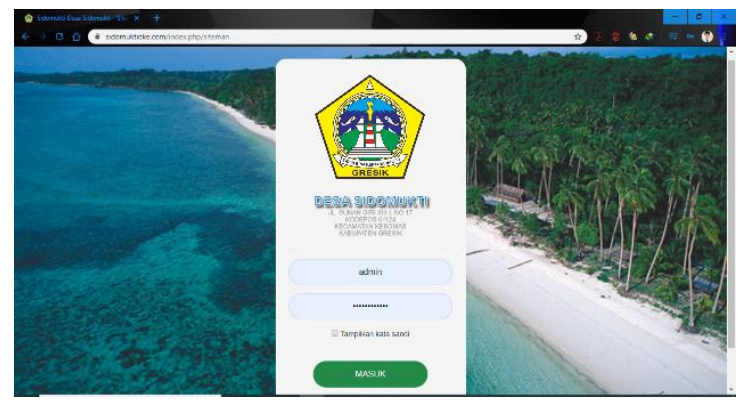

Gambar 1. Tampilan halaman login untuk administrator Sistem web

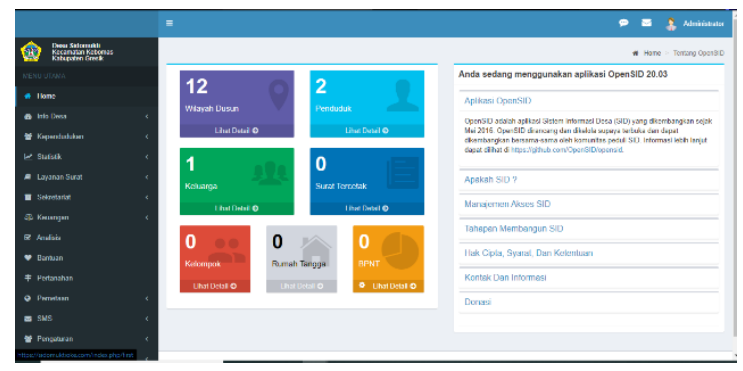

Gambar 2. Tampilan setelah login sebagai administrator 


\section{DedikasiMU (Journal of Community Service)}

Volume 3, Nomor 1 ,Maret 2021

Tahap selanjutnya yaitu menentukan menu-menu apa saja yang akan ditampilkan pada website untuk menyampaikan informasi yang akan disampaikan secara online. Berikut tampilan halaman untuk mengatur susunan menu pada website Kelurahan Sidomukti:

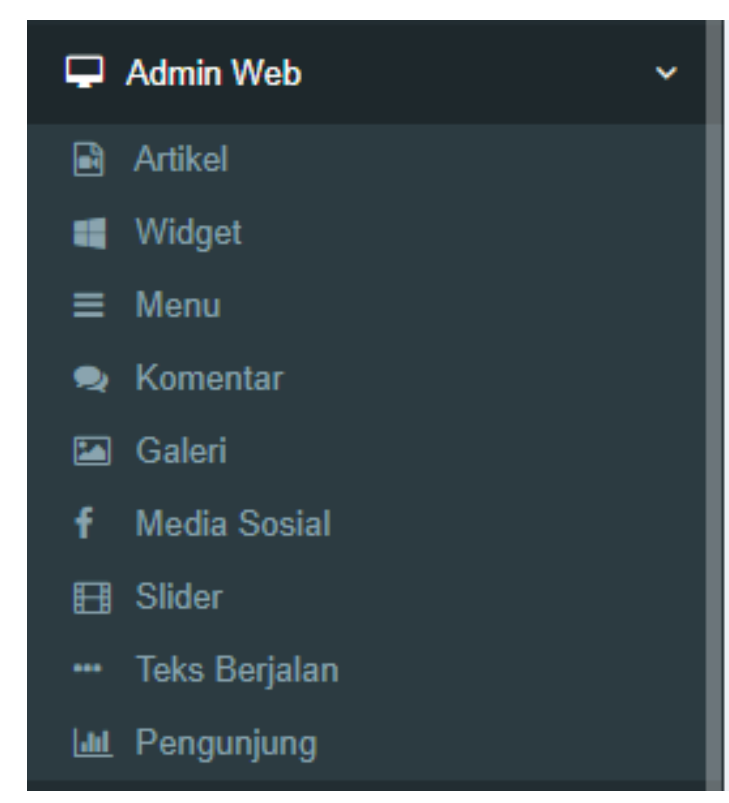

Gambar 3. Tampilan halaman untuk mengatur susunan menu website Kelurahan Sidomukti.

Tahap selanjutnya yaitu menambah isi pada menu. Tiap isi berisikan informasiinformasi tentang Kelurahan Sidomukti. (Sesuai Gambar 3).

Website kelurahan Sidomukti sudah selesai dibuat dengan tahapan-taapan diatas. Dan selanjutnya website Kelurahan Sidomukti siap disosialisasikan kepada perangkat Kelurahan Sidomukti agar website tersebut dapat dikelola dengan baik dan bermanfaat. 


\section{DedikasiMU (Journal of Community Service)}

Volume 3, Nomor 1,Maret 2021

\section{HASIL DAN PEMBAHASAN}

terdapat 2 (dua) Fungsi utama dari website Kelurahan Sidomukti yaitu fungsi yang pertama menjadi media interaksi digital berupa "Pelayanan Mandiri" dimana penduduk kelurahan sidomukti yang telah terdaftar dan mendapatkan PIN dapat mengecek kesesuaian biodata, cetak Kartu Keluarga (Salinan), Mengecek bantuan apa saja yang diterima bahkan mengirimkan saran atau laporan ke perangkat kelurahan secara digital (sesuai Gambar 5) dengan cara mengakses https://sidomuktioke.com/ kemudian login di layanan madiri (sesuai Gambar 4)

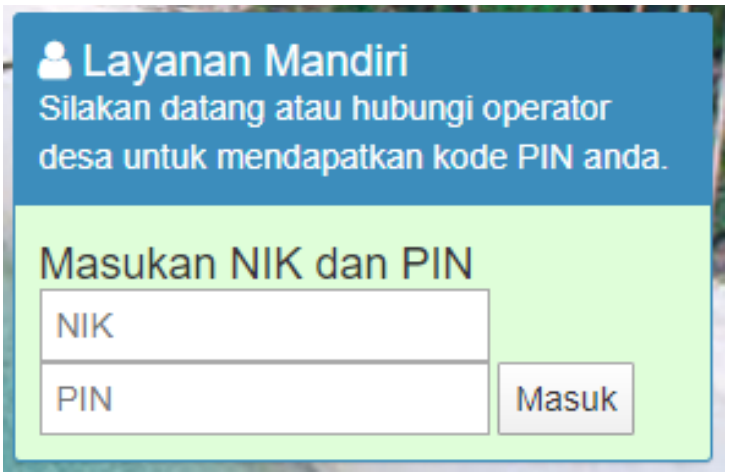

Gambar 4. Tampilan halaman login layanan mandiri untuk penduduk yang telah terdaftar

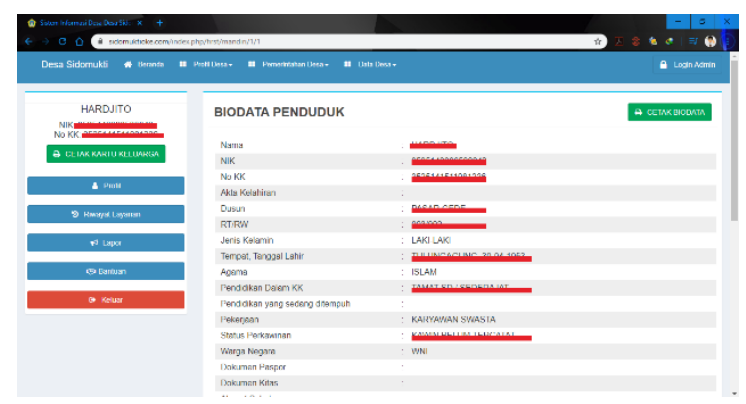

Gambar 5. Tampilan setelah login layanan mandiri

Fungsi yang kedua sebagai sarana publikasi informasi seputar Kelurahan Sidomukti yaitu profil Kelurahan, visi dan misi, program, kegiatan dan produk-produk Kelurahan Sidomukti. Untuk diakses seluruh pengunjung web desa. 


\section{DedikasiMU (Journal of Community Service)}

\section{Volume 3, Nomor 1 ,Maret 2021}

Oleh karena itu Peran pengelola website Desa harus sangat diperhatikan. Sehingga website selalu update tentang informasi-informasi baru yang perlu ditampilkan pada website dan menyampaikan laporan dari masyarakat. Macam-macam user yang disediakan adalah Administrator, Redaksi, dan Operator.

Administrator memiliki hak akses penuh terhadap website. Administrator dapat melakukan segala hal terhadap website yang dikelolanya. Administrator dapat menambah user baru, menghapus user, mengubah peran user terhadap website. Administrator memiliki kontrol penuh terhadap post artikel, halaman-halaman website, dan tema yang diterapkan pada website.

Peran sebagai Administrator ini pada dasarnya disediakan untuk pemilik website dan memberi kontrol penuh terhadap website. Jika menjalankan sebuah website multi-user PHP, maka harus sangat berhati-hati untuk memilih siapa yang akan memiliki peran sebagai Administrator.

Redaksi adalah orang/tim yang bertugas memeriksa dan memperbaiki materi yang ditampilkan di website desa. Biasanya juga berperan menentukan isi website desa.

Operator memiliki hak akses antara lain untuk: Memberikan pelayanan kepada masyarakat menggunakan Sistem web Desa, Mengubah dan menambah artikel terbaru, mengelola dan menyampaikan Laporan / Masukan dari masyarakat, Memasukan bahan artikel, Memasukan bahan untuk menu (menu statis dan dinamis). Mengelola data dan profil desa, Melakukan backup database desa dan folder desa secara rutin.

Halaman pengunjung adalah halaman yang diakses oleh seluruh pengunjung. Pada halaman pengunjung berisi informasi seputar Kelurahan Sidomukti yaitu profil desa, visi dan misi, program, kegiatan dan produk-produk yang dihasilkan Kelurahan Sidomukti.

Pengunjung tidak perlu melakukan proses login untuk melihat halaman website, cukup dengan membuka

\section{https://sidomuktioke.com/}




\section{DedikasiMU (Journal of Community Service)}

Volume 3, Nomor 1,Maret 2021

Berikut ini adalah beberapa tampilan untuk halaman pengunjung :

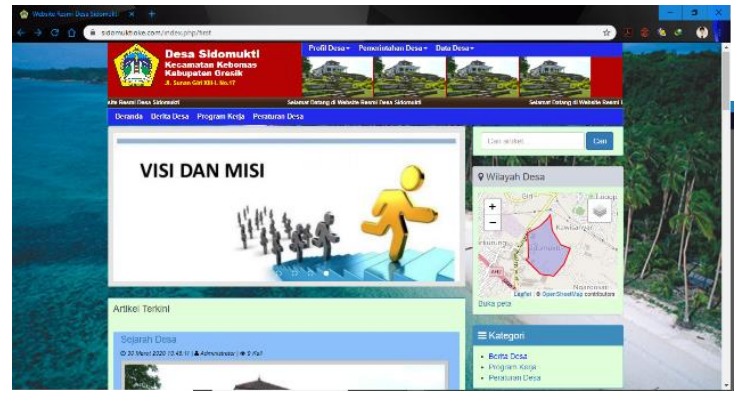

Gambar 6. Tampilan halaman Home pada website Kelurahan Sidomukti berisi tentang artikel dan informasi.

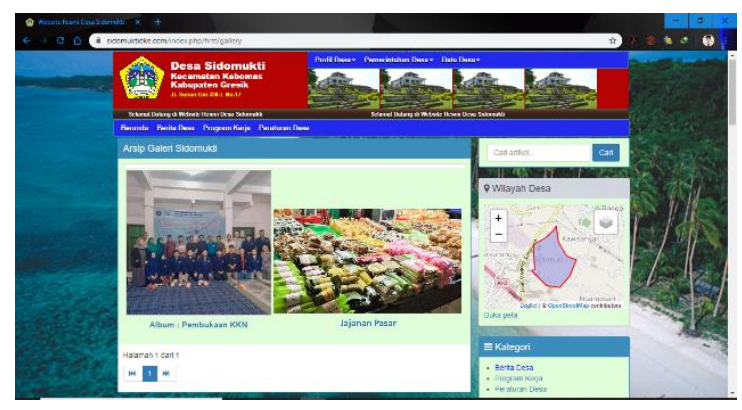

Gambar 7. Galeri Product / kegiatan

\section{KESIMPULAN DAN SARAN}

Website Kelurahan Sidomukti dengan alamat https://sidomuktioke.com/ sebagai sarana publikasi atau penyampaian informasi yang dapat diakses seluruh masyarakat pengguna internet. Website Desa Sidomukti sebagai media untuk meningkatkan pelayanan masyarakat dan mengurangi kesenjangan antara penduduk dan perangkat kelurahan. Website Kelurahan Sidomukti harus selalu update tentang informasi sehingga pengunjung selalu mendapatkan informasi terbaru dari Kelurahan Sidomukti. Baiknya pemerintah kelurahan Sidomukti menyediakan sumber daya khusus untuk mengelola website Desa Sidomukti, agar laporan dari masyarakat dapat tersampaikan dengan baik serta website selalu update dengan info-info terbaru yang berhubungan dengan desa atau lainnya agar selalu menarik untuk dikunjungi. 


\section{DedikasiMU (Journal of Community Service)}

\section{Volume 3, Nomor 1,Maret 2021}

\section{DAFTAR PUSTAKA}

Wikipedia Kategori: Walisongo, Dikutip $12 \quad$ Agustus 2019 dari https://id.wikipedia.org/wiki/Kedatuan_Giri.

Alex, Fahrudin, Bambang, Eka Purnama.Pembangunan Sistem Informasi Layanan Haji Berbasis Web Pada Kelompok Bimbingan Ibadah Haji Ar Rohman Mabrur. 2012. Kudus: Indonesian Jurnal on Computer Science - Speed (IJCSS) 13 Vol 9 No 2 Agustus 2012. ISSN $1979-9330$.

Anhar. Panduan Menguasai PHP \& MySQL Secara Otodidak. 2010. Media Kita. Jakarta.

Hambali,Yusuf.2018. Kategori Pengguna. Dikutip 8 April 2019 dari GitHub,Inc. :https://github.com/OpenSID/opensid/wiki/Pengaturan-Pengguna

Medi,Suhartanto. Pembuatan Website Sekolah Menengah Pertama Negeri 3 Delanggu Dengan Menggunakan Php Dan Mysql. 2012. Indonesian Jurnal on Computer Science - Speed (IJCSS) 15. FTI UNSA.Vol 10 No 1 .Februari 2012. ijcss.unsa.ac.id, ISSN 1979 9330.

Nugroho,Bunafit. Membuat Website Sendiri Deangan PHP-MSQL. 2009. Mediakit. 